\title{
Black carbon contributes to organic matter in young soils in the Morteratsch proglacial area (Switzerland)
}

\author{
E. Eckmeier ${ }^{1}$, C. Mavris ${ }^{2}$, R. Krebs ${ }^{3}$, B. Pichler ${ }^{2}$, and M. Egli ${ }^{2}$ \\ ${ }^{1}$ University of Bonn, INRES - Soil Science and Soil Ecology, Nussallee 13, 53115 Bonn, Germany \\ ${ }^{2}$ Department of Geography, University of Zurich, Winterthurerstrasse 190, 8057 Zurich, Switzerland \\ ${ }^{3}$ Institute of Natural Resource Sciences, Zurich University of Applied Sciences, Wädenswil, Switzerland \\ Correspondence to: E. Eckmeier (eileen.eckmeier@uni-bonn.de)
}

Received: 21 August 2012 - Published in Biogeosciences Discuss.: 11 October 2012

Revised: 14 January 2013 - Accepted: 4 February 2013 - Published: 1 March 2013

\begin{abstract}
Most glacier forefields of the European Alps are being progressively exposed since the glaciers reached their maximum expansion in the 1850s. Global warming and climate changes additionally promote the exposure of sediments in previously glaciated areas. In these proglacial areas, initial soils have started to develop so that they may offer a continuous chronosequence from 0 to 150 -yr-old soils.

The build-up of organic matter is an important factor of soil formation, and not only autochthonous but also distant sources might contribute to its accumulation in young soils and surfaces of glacier forefields. Only little is known about black carbon in soils that develop in glacier forefields, although charred organic matter could be an important component of organic carbon in Alpine soils.

The aim of our study was to examine whether black carbon (BC) is present in the initial soils of a proglacial area, and to estimate its relative contribution to soil organic matter. We investigated soil samples from 35 sites distributed over the whole proglacial area of Morteratsch (Upper Engadine, Switzerland), covering a chronosequence from 0 to $150 \mathrm{yr}$. BC concentrations were determined in fine earth using the benzene polycarboxylic acid (BPCA) marker method. We found that charred organic matter occurred in the whole area, and that it was a main compound of soil organic matter in the youngest soils, where total $\mathrm{C}_{\text {org }}$ concentrations were very low. The absolute concentrations of $\mathrm{BC}$ in fine earth were generally low but increased in soils that had been exposed for more than $40 \mathrm{yr}$. Specific initial microbial communities may profit from this additional $\mathrm{C}$ source during the first years of soil evolution and potentially promote soil development in its early stage.
\end{abstract}

\section{Introduction}

Alpine glacier forefields, or proglacial areas, are defined as the area between the present-day glacier front and the terminal moraines deposited in the 1850 s, when the glaciers reached their maximum expansion. The most evident developments in Alpine soil formation occur in proglacial areas where soil formation follows retreating glaciers, and where recently formed soils are continuously developing (Egli et al., 2006). Increasing temperatures will lead to further retreat of glaciers, and additional areas will become subject to weathering and formation of soil organic matter. Proglacial environments are also important for the understanding of global $\mathrm{CO}_{2}$ cycling on glacial/interglacial timescales as they made up a significant amount of the global land surface during the Quaternary due to the advance and retreat of glaciers and ice sheets (Gibbs and Kump, 1994).

Retreating glaciers often expose barren substrates that become colonised by organisms, beginning the process of primary plant succession which affects the evolution of organic matter in the developing topsoils (Burga et al., 2010). However, not only autochthonous but also distant (allochthonous) sources may contribute to the accumulation of soil organic carbon $\left(\mathrm{C}_{\mathrm{org}}\right)$ in young soils and surfaces of glacier forefields. Among these sources are dry and wet atmospheric deposition, faecal deposit, ground-nesting of birds, soot deposit, input due to photoautotroph organisms, or organic matter of fossil (and preserved) soils (e.g. Bauer et al., 2002; Kim et al., 2005, 2011; Arimitsu et al., 2007; Mindl et al., 2007; Xu et al., 2009; Bogdal et al., 2011; Wientjes et al., 2011). Bernasconi et al. (2011) demonstrated that soil 


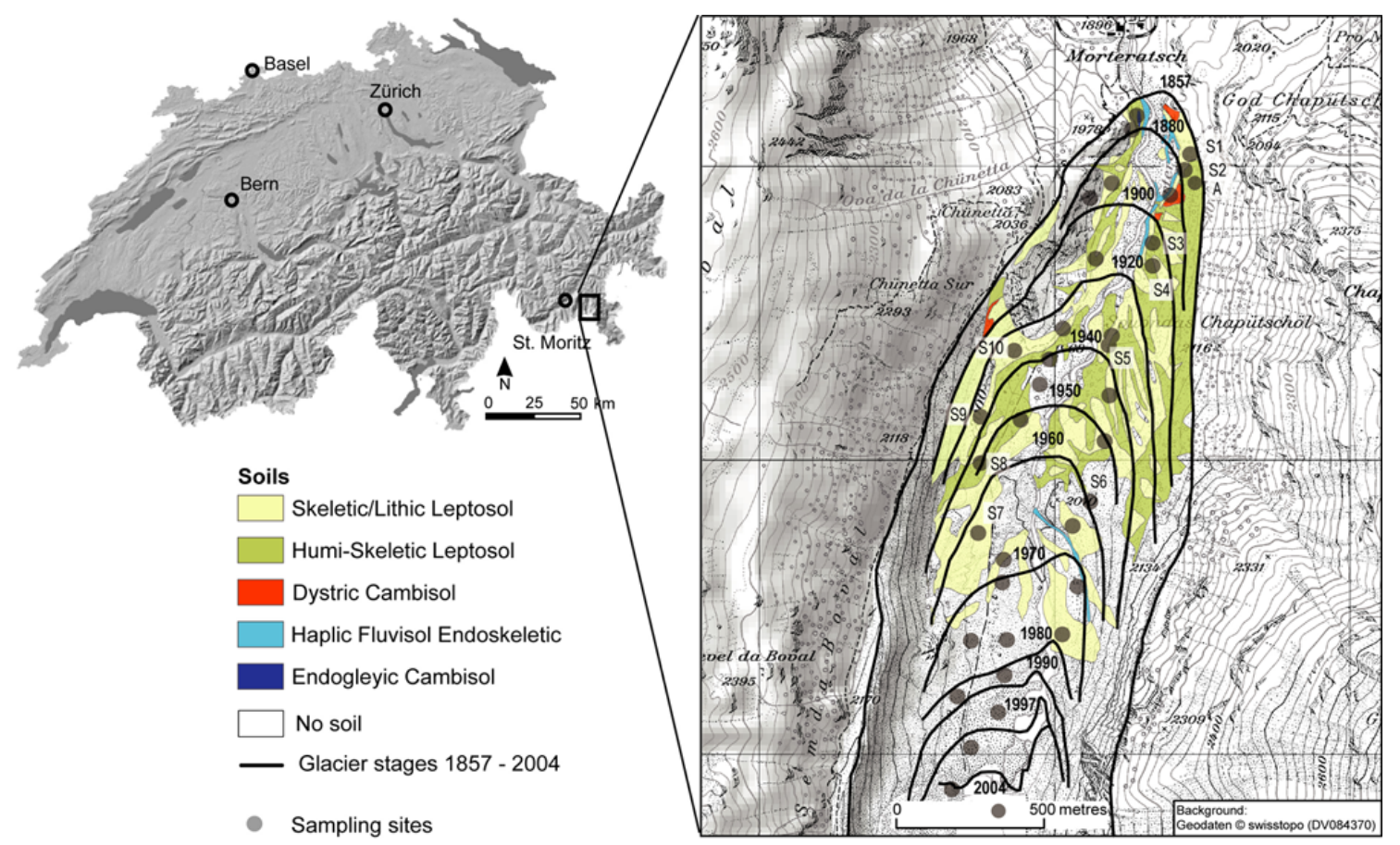

Fig. 1. Location of the Morteratsch glacier forefield with isochrones of glacier retreat, major soil units and position of the topsoil sampling sites, which were analysed in detail regarding soil chemistry and mineralogy (S1-10; Mavris et al., 2010).

organic matter in initial soils of the Damma glacier forefield contains a relatively high proportion of labile organic compounds which are easily oxidisable and have a short turnover time (annual to decadal). Autochthonous recalcitrant organic matter is not formed in significant amounts in this environment at decadal timescales.

Bardgett et al. (2007) measured changes in the composition of microbial communities and their use of carbon compounds along a 150-yr chronosequence in the Austrian Alps. They found that the initial soil microbial communities of the youngest sites were heterotroph organisms that used previously buried recalcitrant carbon, e.g. black carbon, as an energy source. On older sites, after $50 \mathrm{yr}$ of exposure, the soil microorganisms respired modern carbon that derived from modern plant growth.

Charred organic matter and soot, or compounds of black carbon (BC), that were released during vegetation fires or fossil fuel burning are ubiquitous components of soils. Several studies demonstrated that $\mathrm{BC}$ can be an important compound even in Alpine soils (Bucheli et al., 2004, Eckmeier et al., 2010), Alpine lake sediments (Bogdal et al., 2011), or in glacial ice cores (Lavanchy et al., 1999; Thevenon et al., 2009), either due to in situ burning of biomass or via atmospheric deposition. Glaciers can be sources of BC when they release BC with glacial runoff water that has been incorporated into the ice after melting (Stubbins et al., 2012).

Although the build-up of organic $\mathrm{C}$ is an important factor governing the formation of soils and weathering, only very little is known about the presence of BC in very young soils that are developing in glacier forefields. To analyse time trends in such areas, the study of soil chronosequences is an important tool to derive short- to long-term formation rates. The aim of our research was to examine whether BC is an allochthonous source of soil organic matter in the young soils that develop in the proglacial area of the Morteratsch glacier (Upper Engadine, Switzerland) and to estimate its relative contribution (as a function of time) to total organic matter in soils.

\section{Materials and methods}

\subsection{Investigation area}

We investigated soils and sediments of the glacier forefield of Morteratsch in the Upper Engadine (Switzerland), which is limited by the terminal moraines that were deposited during the "Little Ice Age" in the 1850s (Fig. 1). The recent length of this proglacial area is approximately $3 \mathrm{~km}$, and it has an area of $1.8 \mathrm{~km}^{2}$. The proglacial area is situated in a valley that runs $\mathrm{N}$ to $\mathrm{S}$, at an altitude of $1900 \mathrm{~m}$ a.s.l. to about $2050 \mathrm{~m}$ a.s.l. Present climatic conditions are approximately $0.5^{\circ} \mathrm{C}$ mean annual temperature and approximately $1000-1300 \mathrm{~mm}$ mean annual precipitation (calculated from data from the meteorological stations Samedan and Bernina). The geomorphological and climatic history of the Morteratsch glacial environment has 
been studied extensively (cf. Burga and Perret, 1998; Magny, 1992; Maisch, 1992; Renner, 1982; Gamper, 1985; Fitze, 1982; Patzelt, 1977). The glacial till in the glacier forefield represents the parent material of soil formation. It consists of granitoid and gneissic rock material which underwent a "green schist" metamorphic event during the high Alpine orogenesis (Büchi, 1994; Spillmann, 1993; Trommsdorff and Dietrich, 1999). Glacial transportation led to a relatively homogeneous distribution of parent material in the proglacial area.

According to Burga et al. (2010), primary plant succession of the proglacial area started about $7 \mathrm{yr}$ after deglaciation with the Epilobietum fleischeri plant community which includes the species Epilobium fleischeri, Oxyria digyna (only in initial stages), Linaria alpina, Saxifraga aizoides, and Rumex scutatus, and which covered larger areas after about $27 \mathrm{yr}$. First larch trees, willow and green alder shrubs and the first dwarf shrubs (e.g. the rust-leaved alpenrose) appeared on areas which had been ice-free for about 12-15 yr. LarchSwiss stone pine stands (Larici-Pinetum cembrae) needed more than $150 \mathrm{yr}$ to establish. Only small patches of LariciPinetum cembrae can be found on the proglacial area while they are dominant in adjacent areas. The succession was not a linear process and was influenced by various micro-site dependent factors, like soil moisture, grain size, local disturbances or micro-climate, that led to a patchy distribution of plant communities.

The dominant soil units (some sites do not have a soil) in the proglacial area are Haplic Fluvisols (Endoskeletic), Skeletic or Lithic Leptosols and Humi-skeletic Leptosols, and Dystric and Endogleyic Cambisols (Endoskeletic) (IUSS working group, 2006). The youngest soils showed almost no morphological signs of chemical weathering and alteration products. The development of soils in the Morteratsch area during $150 \mathrm{yr}$ of surface exposure, including soil organic matter formation and mineral weathering processes, have been studied in detail (e.g. Egli et al., 2010; Mavris et al., 2010).

\subsection{Methods}

Two sets of samples were investigated that had been taken from the whole proglacial area and that cover a chronosequence ranging from 0 to $150 \mathrm{yr}$ (Table 1). Samples S110 are ten topsoil samples (soil depth between 1 to maximum $12 \mathrm{~cm}$ ) from ten sites, which are shown in Fig. 1. Close to these sites, material from soil pits has been analysed in detail (Mavris et al., 2010). Samples AS1-29 were sampled from additional sites of the proglacial area at a depth of $0-5 \mathrm{~cm}$. All samples have been dried at $105^{\circ} \mathrm{C}$, sieved $(<2 \mathrm{~mm})$ and ball-milled for further analysis.

Total $\mathrm{C}$, nitrogen $(\mathrm{N})$ and hydrogen $(\mathrm{H})$ contents were measured using a $\mathrm{C} / \mathrm{H} / \mathrm{N}$ analyzer (Elementar Vario EL). The organic matter content was determined gravimetrically after dry combustion in a muffle furnace at $550^{\circ} \mathrm{C}$ for $6 \mathrm{~h}$ (No- centini et al., 2010). The oxygen (O) content was calculated from the measured data. Total $\mathrm{C}$ was considered as organic $\mathrm{C}\left(\mathrm{C}_{\text {org }}\right)$ because $\mathrm{CaCO}_{3}$ could not be detected in any sample using $\mathrm{HCl}$, and only traces $(<0.5 \%)$ - if even - could be observed in DRIFT spectra. The soil is acidic $(\mathrm{pH}<6)$ in the whole proglacial area (Mavris et al., 2010).

The concentration of black carbon (BC) in fine-earth samples was determined as benzene polycarboxylic acids (BPCA) according to the method described by Brodowski et al. (2005). The samples (two replicates) were first treated with trifluoroacetic acid (TFA) to remove polyvalent cations and then digested with $\mathrm{HNO}_{3}$ at $170^{\circ} \mathrm{C}$ for eight hours. The sum of BPCAs in each sample was determined after derivatisation on a gas chromatograph equipped with a flame ionisation detector (GC-FID). The patterns of benzene rings are dependent on the degree of condensation of the polyaromatic carbon compounds. We used a conversion factor of 2.27 to estimate BC contents from total BPCA-C concentrations. The factor provides a conservative minimum estimate of the true BC contents in soil (Glaser et al., 1998; Brodowski et al., 2005).

Environmental scanning electron microscopy (ESEM) and energy-dispersive spectroscopy (EDS) were performed on three loose granular samples (uncoated) (AS21, 24, 28) at the Institute for Building Materials (ETH Zurich, Switzerland). The fine-earth fraction of the samples was washed with deionised water, and the floating material (density $<1 \mathrm{~g} \mathrm{~cm}^{-3}$ ) was collected and air-dried. This enabled the selective extraction of the organic fraction of the sediment, including charcoal material. The analysis was performed using a Dual Beam Quanta 200 3D FEI coupled with EDS, with Dual BSD detector and W emitter operating at an accelerating voltage of $20 \mathrm{kV}$. The EDS detector is equipped with an ultra-thin window allowing detection of mineral elements and carbon, which provided the elemental composition of the solid phases.

Soil colour was measured for dried and homogenised soil samples in triplicates using a spectrophotometer (Konica Minolta CM-5) by detecting the diffused reflected light under standardised observation conditions $\left(2^{\circ}\right.$ standard observer, illuminant $\mathrm{C}$ ). The colour spectra were obtained in the 360 to $740 \mathrm{~nm}$ range, in $10 \mathrm{~nm}$ increments. The spectral information was converted into the Munsell colour system and the CIELAB colour space (CIE 1976) using the Software SpectraMagic NX (Konica Minolta). The $L^{*}$ values indicate the extinction of light, or luminance, on a scale from $L^{*} 0$ (absolute black) to $L^{*} 100$ (absolute white).

\section{Results}

\subsection{Organic $\mathrm{C}$ and nitrogen}

The $\mathrm{C}_{\text {org }}$ concentrations ranged from $1.9-131.0 \mathrm{~g} \mathrm{~kg}^{-1}$, with an average of $23.6 \mathrm{~g} \mathrm{~kg}^{-1}$ and a median of $11.5 \mathrm{~g} \mathrm{~kg}^{-1}$ 
Table 1. General properties of the investigated sites in the Morteratsch proglacial area.

\begin{tabular}{|c|c|c|c|c|c|c|c|}
\hline Site & $\begin{array}{c}\text { Year of } \\
\text { exposure }\end{array}$ & $\begin{array}{c}\text { Exposure } \\
\text { time } \\
\mathrm{yr}\end{array}$ & Horizon & $\begin{array}{l}\text { Depth } \\
\mathrm{cm}\end{array}$ & $\begin{array}{l}\text { Skeleton } \\
\text { wt-\% }\end{array}$ & Soil type (WRB) & Vegetation $^{\mathrm{a}}$ \\
\hline $\mathrm{S} 1$ & 1870 & 140 & A & $0-6$ & 41 & Humi-skeletic Leptosol & 4 \\
\hline AS1 & 1870 & 140 & A & $0-5$ & n.d. & Humi-skeletic Leptosol & 2 \\
\hline $\mathrm{S} 2$ & 1880 & 130 & A & $0-10$ & 64 & Humi-skeletic Leptosol & 4 \\
\hline AS2 & 1880 & 130 & A & $0-5$ & n.d. & Humi-skeletic Leptosol & 2 \\
\hline AS3 & 1890 & 120 & A & $0-5$ & n.d. & Humi-skeletic Leptosol & 5 \\
\hline AS4 & 1890 & 120 & A & $0-5$ & n.d. & Skeletic Leptosol & 2 \\
\hline S3 & 1900 & 110 & A & $0-5$ & 54 & Humi-skeletic Leptosol & 3 \\
\hline AS5 & 1900 & 110 & $\mathrm{~A}$ & $0-5$ & n.d. & Skeletic Leptosol & 7 \\
\hline S4 & 1910 & 100 & A & $0-1$ & 55 & Humi-skeletic Leptosol & 3 \\
\hline AS6 & 1910 & 100 & $\mathrm{AC}$ & $0-5$ & n.d. & Skeletic Leptosol & 2 \\
\hline AS8 & 1920 & 90 & $\mathrm{AC}$ & $0-5$ & n.d. & Skeletic Leptosol & 6 \\
\hline S10 & 1930 & 80 & A1 & $0-2$ & 49 & Humi-skeletic Leptosol & 3 \\
\hline AS9 & 1930 & 80 & $\mathrm{AC}$ & $0-5$ & n.d. & Skeletic Leptosol & 4 \\
\hline S9 & 1935 & 75 & $\mathrm{O}$ & $0-3$ & 44 & Humi-skeletic Leptosol & 2 \\
\hline S5 & 1940 & 70 & A1 & $0-1$ & 7 & Humi-skeletic Leptosol & 2 \\
\hline AS10 & 1940 & 70 & A & $0-5$ & n.d. & Humi-skeletic Leptosol & 2 \\
\hline AS11 & 1945 & 65 & $\mathrm{~A}$ & $0-5$ & n.d. & Humi-skeletic Leptosol & 3 \\
\hline AS12 & 1945 & 65 & A & $0-5$ & n.d. & Skeletic Leptosol & 3 \\
\hline S8 & 1950 & 60 & $\mathrm{O} / \mathrm{A}$ & $0-12$ & 63 & Skeletic Leptosol & 2 \\
\hline AS13 & 1950 & 60 & A & $0-5$ & n.d. & Skeletic Leptosol & 3 \\
\hline AS14 & 1950 & 60 & A & $0-5$ & n.d. & Humi-skeletic Leptosol & 3 \\
\hline S6 & 1960 & 50 & A & $0-3$ & 64 & Skeletic Leptosol & 3 \\
\hline S7 & 1960 & 50 & A & $0-4$ & 26 & Skeletic Leptosol & 2 \\
\hline AS15 & 1965 & 45 & A & $0-5$ & n.d. & Skeletic Leptosol & 2 \\
\hline AS16 & 1965 & 45 & $(\mathrm{~A}) \mathrm{C}$ & $0-5$ & n.d. & Skeletic Leptosol & 3 \\
\hline AS17 & 1970 & 40 & $\mathrm{AC}$ & $0-5$ & n.d. & Skeletic Leptosol & 3 \\
\hline AS18 & 1970 & 40 & $\mathrm{AC}$ & $0-5$ & n.d. & Skeletic Leptosol & 3 \\
\hline AS19 & 1975 & 35 & $(\mathrm{~A}) \mathrm{C}$ & $0-5$ & n.d. & - & 3 \\
\hline AS20 & 1975 & 35 & (A)C & $0-5$ & n.d. & - & 3 \\
\hline $\mathrm{AS} 21$ & 1975 & 35 & (A)C & $0-5$ & n.d. & - & 3 \\
\hline AS22 & 1980 & 30 & (A)C & $0-5$ & n.d. & - & 0 \\
\hline AS23 & 1980 & 30 & (A)C & $0-5$ & n.d. & - & 3 \\
\hline AS24 & 1990 & 20 & (A)C & $0-5$ & n.d. & - & 0 \\
\hline AS28 & 2007 & 3 & $\mathrm{C}$ & $0-5$ & n.d. & - & 0 \\
\hline AS29 & 2007 & 3 & $\mathrm{C}$ & $0-5$ & n.d. & - & 0 \\
\hline $\begin{array}{l}\text { n.d. }=\text { not } \\
\text { a } 0=\text { no ve } \\
2=\text { pioneer } \\
3=\text { Epilob } \\
4=\text { green a } \\
\text { flexuosa, } N \\
5=\text { grass } \\
6=\text { boulde } \\
\text { spec., Athy }\end{array}$ & $\begin{array}{l}\text { etermined. } \\
\text { etation; } \\
\text { grass commun } \\
\text { tum fleischeri } \\
\text { der scrub (Alne } \\
\text { rdus stricta, Fe } \\
\text { ath on moister } \\
\text { plant commun }\end{array}$ & $\begin{array}{l}\text { ies (Geo montc } \\
\text { ith single will } \\
\text { um viridis) }(A l l \\
\text { stuca spec., } P h l \\
\text { oils (grass spec } \\
\text { ies, partially } E_{l}\end{array}$ & $\begin{array}{l}\text { i-Nardetum ar } \\
\mathrm{v} \text { shrubs and a } \\
\text { is viridis and } \\
\text { um rhaeticum } \\
\text { es, e.g. Festuc } \\
\text { lobietum fleis }\end{array}$ & $\begin{array}{l}\mathrm{d} \text { Poion alp } \\
\text { penrose; } \\
\text { all perennial } \\
\text { Anthoxanth } \\
\text { violacea, } \\
\text { heri (Epilob }\end{array}$ & $\begin{array}{l}\text { lae); } \\
\text { herbs, Salix } \mathrm{s} \\
\text { im alpinum, } \\
\text { alamagrostis } \\
\text { um fleischeri } \\
\text { ); }\end{array}$ & $\begin{array}{l}\text { c., Poa spec., Deschampsia caes, } \\
\text { lamagrostis villosa); } \\
\text { losa, Phleum rhaeticum, Poa alp } \\
\text { denostyles leucophylla, Rumex s }\end{array}$ & $\begin{array}{l}\text { tosa, Avenella } \\
\text { a); }\end{array}$ \\
\hline
\end{tabular}

(Table 2). Figure 2 shows that the $\mathrm{C}_{\text {org }}$ concentrations in younger soils did not exceed $5 \mathrm{~g} \mathrm{~kg}^{-1}$, while after about $40 \mathrm{yr}$ of surface exposure the $\mathrm{C}_{\text {org }}$ concentrations increased, and reached values of up to $90 \mathrm{~g} \mathrm{~kg}^{-1}$ at about $60 \mathrm{yr}$, and a maximum of $131 \mathrm{~g} \mathrm{~kg}^{-1}$ at $75 \mathrm{yr}$. There is, however, a strong scatter of $\mathrm{C}_{\text {org }}$ concentrations that is not only related to the factor of time but also to others such as vegetation. The average $\mathrm{C}_{\text {org }}$ concentrations were higher under pioneer grass commu- nities $\left(46 \mathrm{~g} \mathrm{~kg}^{-1}, 10\right.$ sites; vegetation type 2 in Table 1$)$ than under the Epilobietum fleischeri sites $\left(17 \mathrm{~g} \mathrm{~kg}^{-1}, 15\right.$ sites; vegetation type 3 ). Only three sites were covered by plants that belong to the green alder scrub communities (Alnetum viridis), they reached an average of $15 \mathrm{~g} \mathrm{C}_{\mathrm{org}} \mathrm{kg}^{-1}$.

The $\mathrm{N}$ concentrations ranged from 0.2 to $7.0 \mathrm{~g} \mathrm{~kg}^{-1}$ (mean 1.3 , median $0.8 \mathrm{~g} \mathrm{~kg}^{-1}$ ). The $\mathrm{C} / \mathrm{N}$ ratios were between 2 and 58 (mean 19, median 15). For samples S1-10 
Table 2. Spectral and chemical properties of the fine-earth fraction $(<2 \mathrm{~mm})$.

\begin{tabular}{|c|c|c|c|c|c|c|c|c|c|c|c|c|c|}
\hline \multirow[t]{2}{*}{ Site } & \multirow{2}{*}{$\begin{array}{c}\text { Exposure } \\
\text { time } \\
\text { yr }\end{array}$} & \multirow{2}{*}{$\begin{array}{c}\text { Luminance } \\
L^{*}\end{array}$} & \multicolumn{3}{|c|}{ Munsell colour } & \multirow{2}{*}{$\begin{array}{c}\mathrm{C}_{\text {org }} \\
\mathrm{g} \mathrm{kg}^{-1}\end{array}$} & \multirow{2}{*}{$\begin{array}{c}\mathrm{N} \\
\mathrm{g} \mathrm{kg}^{-1}\end{array}$} & \multirow{2}{*}{$\begin{array}{c}\mathrm{C} / \mathrm{N} \\
\text { Weight ratio }\end{array}$} & \multirow{2}{*}{\multicolumn{2}{|c|}{$\begin{array}{l}\mathrm{O} / \mathrm{C} \quad \mathrm{H} / \mathrm{C} \\
\text { Atomic ratio }\end{array}$}} & \multirow{2}{*}{$\begin{array}{c}\mathrm{BC}^{\mathrm{a}} \\
\mathrm{g} \mathrm{C} \mathrm{kg}^{-1} \mathrm{C}_{\text {org }}\end{array}$} & \multirow{2}{*}{$\begin{array}{c}\mathrm{BC}^{\mathrm{a}} \\
\mathrm{g} \mathrm{kg}^{-1}\end{array}$} & \multirow{2}{*}{$\begin{array}{c}\text { B6CA } \\
\%\end{array}$} \\
\hline & & & Hue & Value & Chroma & & & & & & & & \\
\hline S1 & 140 & 57.9 & $2.5 \mathrm{Y}$ & 5.6 & 1.5 & 7.1 & 0.6 & 12 & 0.7 & 1.0 & 49.7 & 0.4 & 27.8 \\
\hline AS1 & 140 & 47.5 & $1.6 \mathrm{Y}$ & 4.6 & 1.5 & 61.2 & 4.6 & 13 & 0.6 & 1.8 & 43.1 & 2.5 & 26.3 \\
\hline S2 & 130 & 40.2 & $0.8 \mathrm{Y}$ & 3.9 & 1.1 & 64.1 & 3.0 & 22 & 0.5 & 0.8 & 43.2 & 2.8 & 22.8 \\
\hline AS2 & 130 & 48.1 & $2.2 \mathrm{Y}$ & 4.7 & 1.8 & 18.1 & 1.2 & 15 & 0.5 & 1.6 & 48.8 & 0.8 & 19.5 \\
\hline AS3 & 120 & 58.3 & $2.9 \mathrm{Y}$ & 5.7 & 1.5 & 7.3 & 0.3 & 23 & 0.7 & 0.3 & 54.5 & 0.4 & 43.9 \\
\hline AS4 & 120 & 54.8 & $2.3 \mathrm{Y}$ & 5.3 & 1.7 & 9.4 & 0.4 & 24 & 0.8 & 0.4 & 49.9 & 0.5 & 38.5 \\
\hline S3 & 110 & 51.6 & $2.3 \mathrm{Y}$ & 5.0 & 1.4 & 30.3 & 1.0 & 29 & 0.4 & 1.3 & 33.1 & 1.0 & 27.7 \\
\hline AS5 & 110 & 47.2 & $1.9 \mathrm{Y}$ & 4.6 & 1.7 & 14.2 & 1.4 & 10 & 1.0 & 0.7 & 58.1 & 0.8 & 28.4 \\
\hline S4 & 100 & 39.0 & $1.4 \mathrm{Y}$ & 3.8 & 1.5 & 54.5 & 1.2 & 47 & 0.7 & 1.7 & 25.8 & 1.4 & 20.7 \\
\hline AS6 & 100 & 62.2 & $3.1 \mathrm{Y}$ & 6.1 & 1.3 & 3.2 & 0.7 & 4 & 1.3 & 2.2 & 136.7 & 0.4 & 49.9 \\
\hline AS8 & 90 & 63.9 & $2.5 \mathrm{Y}$ & 6.2 & 1.6 & 3.9 & 0.4 & 10 & 0.2 & 1.7 & n.d. & n.d. & n.d. \\
\hline S10 & 80 & 38.4 & $1.4 \mathrm{Y}$ & 3.7 & 1.3 & 47.9 & 1.3 & 36 & 0.9 & 1.6 & 44.9 & 2.1 & 14.5 \\
\hline AS9 & 80 & 62.6 & $3.4 \mathrm{Y}$ & 6.1 & 1.4 & 5.3 & 0.6 & 9 & 1.2 & 1.5 & 44.7 & 0.2 & 28.8 \\
\hline S9 & 75 & 39.4 & $0.5 \mathrm{Y}$ & 3.8 & 1.4 & 131.0 & 7.0 & 19 & 0.7 & 1.6 & 42.8 & 5.6 & 13.5 \\
\hline S5 & 70 & 57.1 & $2.5 \mathrm{Y}$ & 5.6 & 1.1 & 31.7 & 0.8 & 42 & 0.6 & 1.1 & 40.2 & 1.3 & 26.1 \\
\hline AS 10 & 70 & 49.5 & $2.0 \mathrm{Y}$ & 4.8 & 1.8 & 29.9 & 1.1 & 28 & 0.5 & 0.8 & 61.4 & 1.8 & 23.6 \\
\hline AS11 & 65 & 49.4 & $2.1 \mathrm{Y}$ & 4.8 & 1.7 & 11.6 & 0.8 & 14 & 0.7 & 0.5 & 46.6 & 0.5 & 24.4 \\
\hline AS 12 & 65 & 43.8 & $1.8 \mathrm{Y}$ & 4.3 & 1.6 & 12.6 & 0.7 & 19 & 0.7 & 0.4 & 30.2 & 0.4 & 24.1 \\
\hline S8 & 60 & 45.1 & $1.7 \mathrm{Y}$ & 4.4 & 1.2 & 89.7 & 3.8 & 24 & 0.6 & 1.5 & 25.9 & 2.3 & 14.8 \\
\hline AS 13 & 60 & 47.6 & $2.2 \mathrm{Y}$ & 4.6 & 1.3 & 11.5 & 0.4 & 30 & 0.5 & 0.9 & 27.1 & 0.3 & 25.3 \\
\hline AS14 & 60 & 58.5 & $2.7 \mathrm{Y}$ & 5.7 & 1.4 & 18.1 & 0.3 & 58 & 0.6 & 1.4 & 23.7 & 0.4 & 22.0 \\
\hline S6 & 50 & 48.1 & $1.4 \mathrm{Y}$ & 4.7 & 1.8 & 37.0 & 1.1 & 34 & 0.3 & 1.6 & 27.9 & 1.0 & 33.6 \\
\hline S7 & 50 & 43.2 & $1.6 \mathrm{Y}$ & 4.2 & 1.7 & 64.5 & 4.3 & 15 & 0.6 & 1.6 & 23.0 & 1.5 & 21.6 \\
\hline AS15 & 45 & 49.7 & $2.3 \mathrm{Y}$ & 4.8 & 1.6 & 18.3 & 0.3 & 57 & 0.8 & 1.6 & 48.0 & 0.9 & 16.6 \\
\hline AS16 & 45 & 61.7 & $2.7 \mathrm{Y}$ & 6.0 & 1.2 & 4.9 & 1.4 & 3 & 1.2 & 1.4 & 46.4 & 0.2 & 24.3 \\
\hline AS17 & 40 & 58.6 & $2.2 \mathrm{Y}$ & 5.7 & 1.6 & 6.0 & 1.0 & 6 & 0.3 & 1.2 & 50.1 & 0.3 & 23.2 \\
\hline AS 18 & 40 & 59.1 & $2.6 \mathrm{Y}$ & 5.8 & 1.5 & 9.3 & 0.4 & 25 & 0.8 & 0.9 & 35.6 & 0.3 & 20.4 \\
\hline AS 19 & 35 & 69.6 & $2.4 \mathrm{Y}$ & 6.8 & 1.4 & 2.3 & 1.0 & 2 & 0.2 & 1.4 & n.d. & n.d. & n.d. \\
\hline AS 20 & 35 & 59.9 & $3.0 \mathrm{Y}$ & 5.8 & 1.5 & 4.1 & 1.3 & 3 & 0.0 & 1.8 & 67.7 & 0.3 & 22.3 \\
\hline AS21 & 35 & 54.7 & $3.1 \mathrm{Y}$ & 5.3 & 1.5 & 4.0 & 0.7 & 5 & 0.0 & 0.1 & n.d. & n.d. & n.d. \\
\hline AS22 & 30 & 59.7 & $3.7 \mathrm{Y}$ & 5.8 & 1.4 & 2.9 & 0.3 & 10 & 0.3 & 2.1 & 69.2 & 0.2 & 22.7 \\
\hline AS23 & 30 & 64.7 & $4.2 \mathrm{Y}$ & 6.3 & 1.3 & 2.6 & 0.2 & 11 & 0.6 & 0.3 & 73.7 & 0.2 & 22.9 \\
\hline AS24 & 20 & 63.8 & $3.8 \mathrm{Y}$ & 6.2 & 1.4 & 2.9 & 0.4 & 7 & 0.0 & 2.2 & n.d. & n.d. & n.d. \\
\hline AS28 & 3 & 62.5 & $4.3 \mathrm{Y}$ & 6.1 & 1.3 & 1.9 & 0.7 & 3 & 0.9 & 0.4 & 117.9 & 0.2 & 22.6 \\
\hline AS29 & 3 & 60.3 & $4.5 \mathrm{Y}$ & 5.9 & 1.2 & 2.1 & 0.3 & 8 & 0.7 & 2.8 & n.d. & n.d. & n.d. \\
\hline
\end{tabular}

a Black carbon was calculated by multiplying BPCA-C data with a conversion factor of 2.27 (Brodowski et al., 2005).

which were taken only from topsoil, the $\mathrm{C} / \mathrm{N}$ ratio was between 12 and 36. The distribution of $\mathrm{N}$ shows a close relationship to the vegetation type and only five sites contained more than $1.4 \mathrm{~g} \mathrm{~N} \mathrm{~kg}^{-1}$, of which four were covered by pioneer grass communities (Geo montani-Nardetum and Poion alpinae, vegetation type 2 ) and one by green alder scrub communities (Alnetum viridis, vegetation type 4).

\subsection{Black carbon}

The BC concentrations (calculated with a conversion factor from BPCA-C) varied between 0.2 and $5.6 \mathrm{~g} \mathrm{~kg}^{-1}$, with an average mean of 1.0 and a median of $0.5 \mathrm{~g} \mathrm{~kg}^{-1}$ (Table 2). Since the proportion of BPCA-C at $\mathrm{C}_{\text {org }}$ exceeded $1.2 \mathrm{~g} \mathrm{~kg}^{-1}$ $\mathrm{C}_{\text {org }}$ (without conversion factor), we can exclude competing biogenic sources that could significantly add to the BC concentrations (Brodowski et al., 2005).

The concentrations of $\mathrm{BC}$, like the $\mathrm{C}_{\text {org }}$ concentrations, were higher in soils that have been developing for more than
40 yr. The $\mathrm{BC}$ and $\mathrm{C}_{\mathrm{org}}$ concentrations were highly correlated $\left(R^{2}=0.89, p<0.001\right)$. The proportion of $\mathrm{BC}$ to total $\mathrm{C}_{\text {org }}$ was between 23 and $137 \mathrm{~g} \mathrm{BC} \mathrm{kg}^{-1} \mathrm{C}_{\text {org }}$ (mean 50, median $46 \mathrm{~g} \mathrm{BC} \mathrm{kg}^{-1} \mathrm{C}_{\text {org }}$ ). When excluding sample AS6, which was considered an outlier, the relationship with time of surface exposure reaches $R^{2}=0.4$ on a logarithmic scale $(y=-16.4 \ln (x)+114.35)$, as shown in Fig. 3 . The youngest soils $(<40 \mathrm{yr})$ contained the highest proportion of $\mathrm{BC}$ (68-118 $\mathrm{g} \mathrm{BC} \mathrm{kg}^{-1} \mathrm{C}_{\text {org }}$ ), while $\mathrm{C}_{\text {org }}$ concentrations were low $\left(2-4 \mathrm{~g} \mathrm{~kg}^{-1}\right)$.

The relative distribution of $\mathrm{B} 6 \mathrm{CA}$ (6 carboxyls) to total BPCAs was $25 \%$ on average, with a tendency towards larger contributions of B6CA on older sites (Fig. 4). The patterns of benzene rings were generally similar for all samples, with the exception of AS6 where the proportion of B6CA reached $50 \%$. 


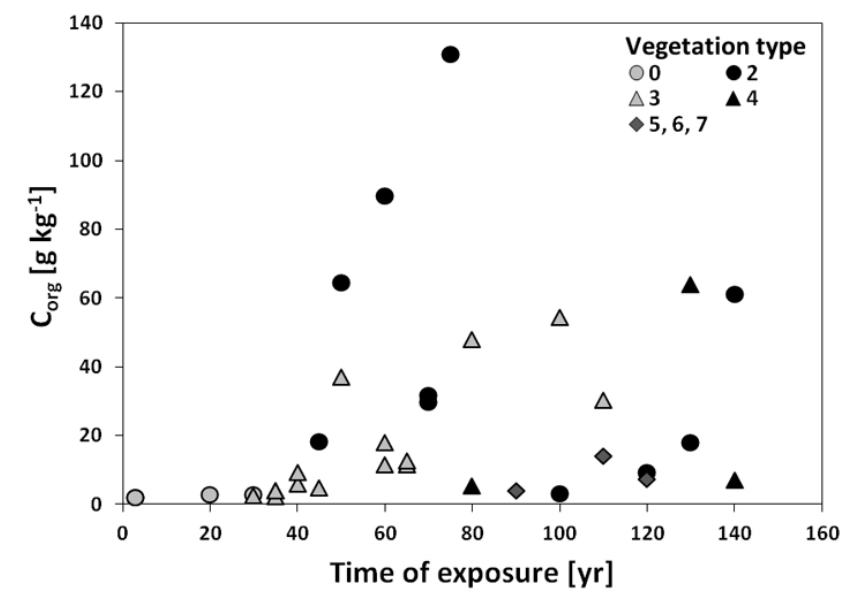

Fig. 2. $\mathrm{C}_{\text {org }}$ concentrations (in $\mathrm{g} \mathrm{kg}^{-1}$ ) in all samples as a function of surface exposure time and vegetation cover. The vegetation types are related to the numbers given in Table 1.

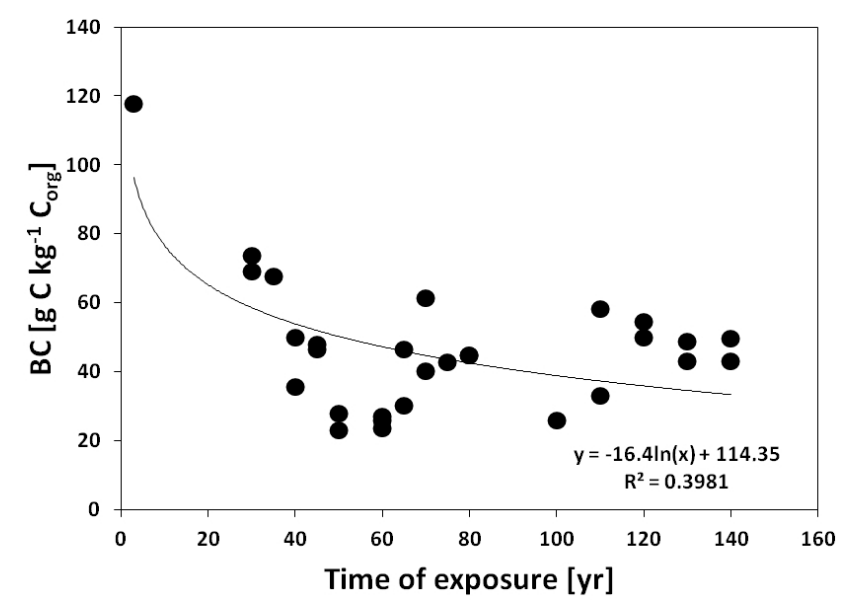

Fig. 3. Relative proportion of $\mathrm{BC}$ in total organic carbon as a function of time for all samples. Sample AS6 was classified as an outlier and removed from the regression.

\subsection{Atomic ratios $\mathrm{O} / \mathrm{C}$ and $\mathrm{H} / \mathrm{C}$}

The $\mathrm{O} / \mathrm{C}$ ratios varied from 0.0 to 1.3 , the $\mathrm{H} / \mathrm{C}$ ratios from 0.1 to 2.8. There was no significant relation between $\mathrm{O} / \mathrm{C}$ ratios and $\mathrm{BC}$ concentrations or the proportion of $\mathrm{BC}$ at $\mathrm{C}_{\text {org }}$. The position of the samples in the van Krevelen plot in Fig. 5 (after Kim et al., 2003) showed that the average atomic ratios for most age groups are typical for plant lignin or cellulose material, with the exception of the youngest age group (0-20 yr) which was characterized by lower $\mathrm{H} / \mathrm{C}$ ratios.

\subsection{ESEM-EDS}

ESEM-EDS allowed the identification of charcoal particles based on their morphology and elemental composition in all analysed samples (AS21, 24, 28), as shown in Fig. 6. The visual identification was supplemented with the measurement

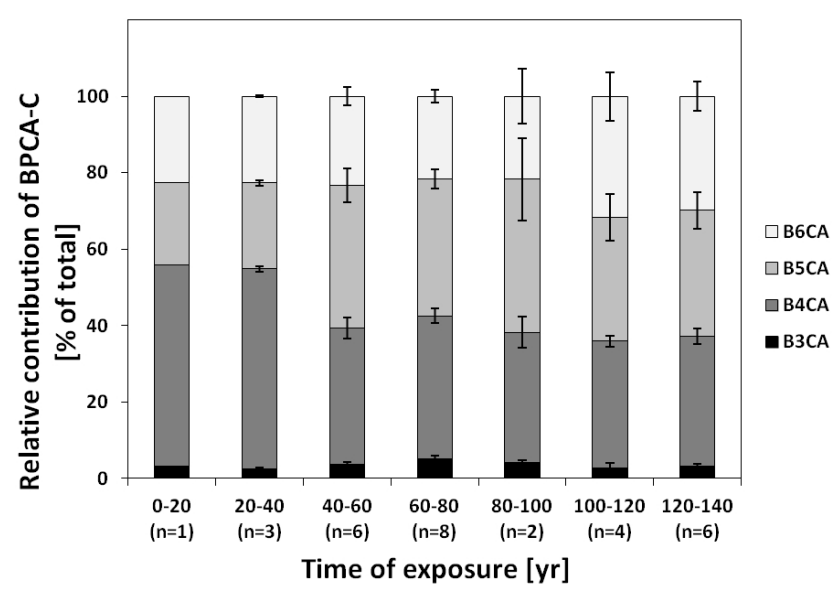

Fig. 4. Average patterns of benzene rings in proportion to total BPCA-C, showing a trend towards larger contributions of B6CA in soil material on older surfaces. Outlier AS6 is included in the age group 100-120. The standard error is given for samples of the corresponding group of time of exposure.

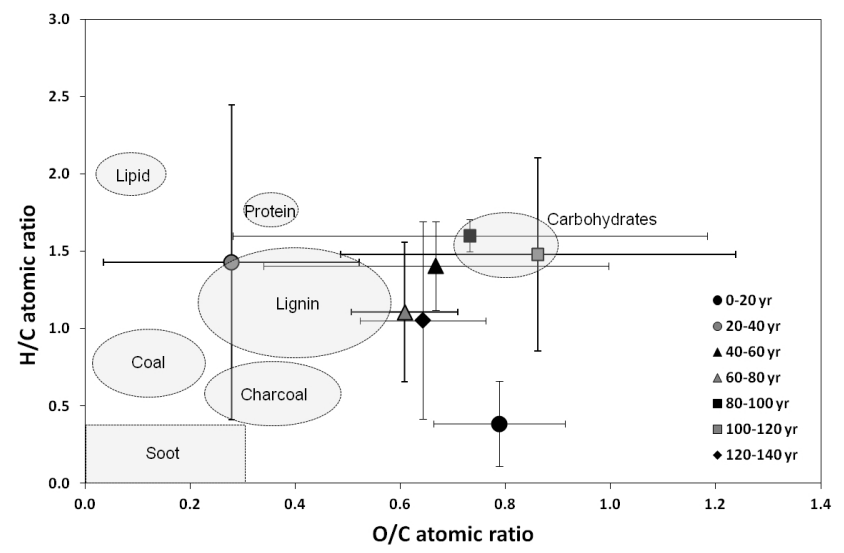

Fig. 5. Van Krevelen diagram showing the $\mathrm{H} / \mathrm{C}$ and $\mathrm{O} / \mathrm{C}$ atomic ratios of soils (mean values \pm standard deviation of age classes). Grey shaded areas indicate areas of organic compounds after Kim et al. (2003) and Hammes et al. (2006).

of the atomic ratios of the particles. Following Brodowski et al. (2005), we considered BC as particles that had an O/C ratio of $\leq 0.33$ (Stoffyn-Egli et al., 1997) on at least one point of an observed particle.

\subsection{Soil colour}

Soil colour, in particular the luminance or brightness of the soil colour $\left(L^{*}\right)$, varied between 38 and 70 (mean 54, median 55). It correlated with $\mathrm{C}_{\mathrm{org}}\left(R^{2}=0.545, p<0.001\right)$ and $\mathrm{BC}$ concentrations $\left(R^{2}=0.462, p<0.001\right)$, but not with time of exposure. 
A)

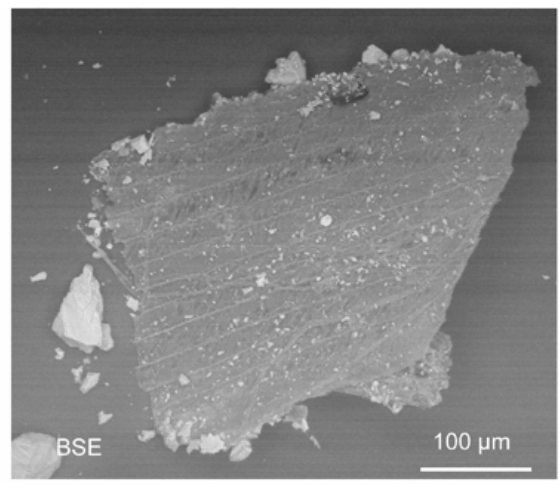

B)

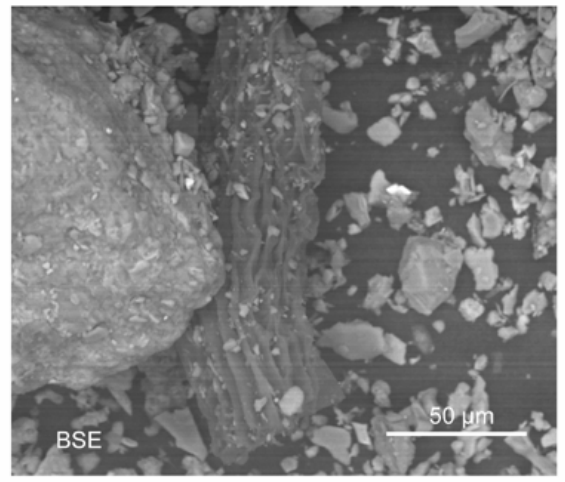

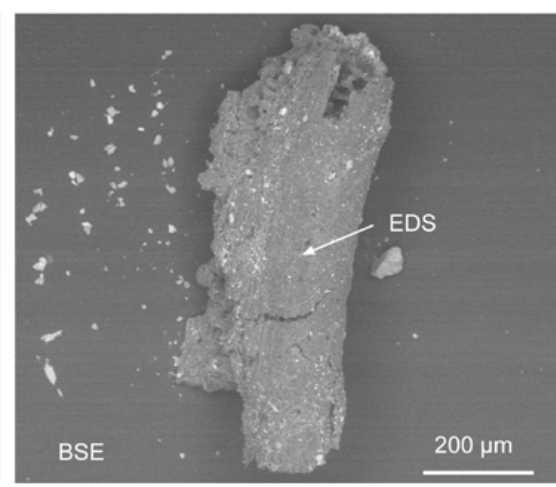

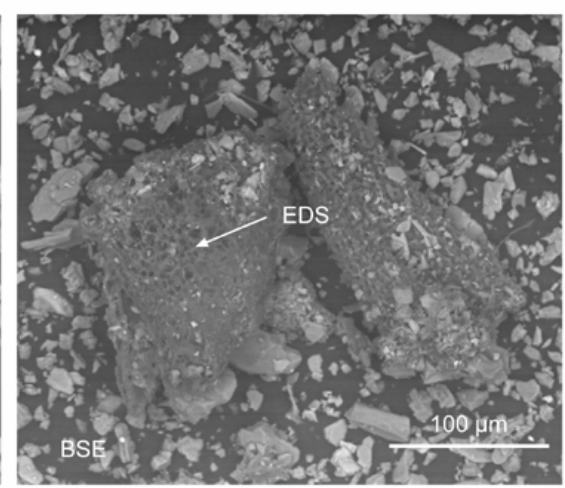

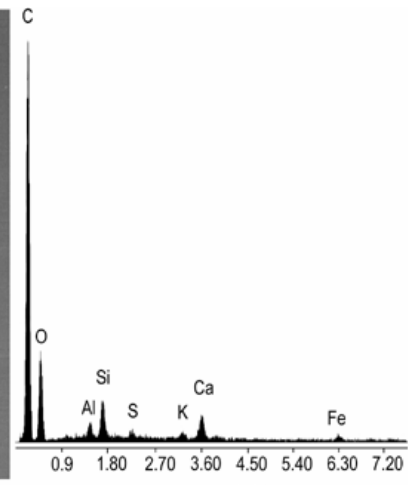

$\mathrm{keV}$

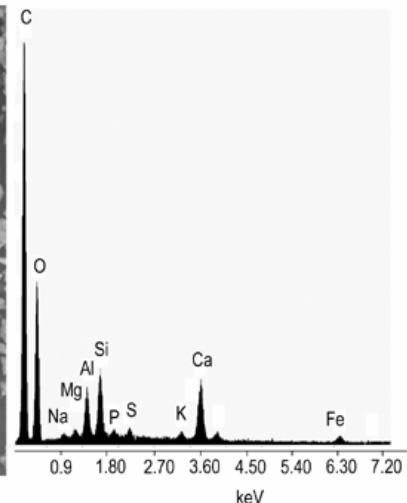

Fig. 6. Environmental scanning electron microscopy (ESEM) and energy-dispersive spectroscopy (EDS) on organic particles (charcoal) with a density $<1 \mathrm{~g} \mathrm{~cm}^{-3}$. (A) Exposure age three years (sample AS29); (B) exposure age $20 \mathrm{yr}$ (sample AS24). BSE = back-scattered electrons.

\section{Discussion}

Although the environmental conditions in the Morteratsch proglacial area are relatively homogeneous, small-scale variability affects the properties of the developing soils. This is reflected, among others, in the $\mathrm{C}_{\text {org }}$ concentrations which considerably varied after 30 to $40 \mathrm{yr}$ of soil evolution. Small changes such as water content of the substrate, the microrelief and micro-climate seem to be crucial for both the development of the vegetation and, consequently, also the early evolution of the soils. Two vegetation types persisted over large parts of the chronosequence: pioneer grass communities (Geo montani-Nardetum and Poion alpinae, vegetation type 2) and Epilobietum fleischeri with single willow shrubs and alpenrose (vegetation type 3 ). The $\mathrm{C}_{\text {org }}$ and $\mathrm{N}$ concentrations were affected by these differences in vegetation; the average concentrations were highest under the pioneer grass communities. Oehl et al. (2011) found, for example, that Epilobium fleischeri is strongly arbuscular mycorrhizal, but plants at closest distance to the glacier were non-mycorrhizal, which finally also influences the $\mathrm{C} / \mathrm{N}$ ratio in a soil.

The variability of soil organic matter under all vegetation types was high, also due to the temporal trend. The soil colours reflected the heterogeneity of soil formation. Due to their low evolution stage, the soils had a relatively light colour but darkened progressively with increasing $\mathrm{C}_{\text {org }}$ and BC contents (cf. Eckmeier et al., 2010). The yellow hues showed that the soils were not visibly affected by soil forming processes, e.g. brunification, yet.

$\mathrm{BC}$ was present in the whole investigated area, independent from the time since the surface was exposed, although the concentrations were very low in the youngest soils. The occurrence of $\mathrm{BC}$ in remote mountainous environments is not unusual. $\mathrm{BC}$, or, more generally, combustion residues that have been transported as aerosols, was deposited on the surfaces of Tibetan glaciers (Xu et al., 2009). Stubbins et al. (2012) found that fossil dissolved organic matter in runoff water of glaciers in Alaska was dominated by aerosols produced during combustion, and that these are a major element in the carbon cycle of glacial environments. BC is also commonly found in the Alpine environments of Switzerland. In the sediments of lakes Thun, Engstlen and Oberaar, up to one-third of $\mathrm{C}_{\text {org }}$ was BC (determined by CTO-375; Bogdal et al., 2011). The analysis of ice cores from Colle Gnifetti showed that the deposition of $\mathrm{BC}$ increased strongly since the end of the 19th century (Thevenon et al., 2009). The same trend was measured for polycyclic aromatic hydrocarbons (PAHs), which are also produced during burning and which are likely to be absorbed by BC particles. PAH concentrations reached a maximum in 1945-1955, and then decreased again. A source assignment using specific PAHs indicated 
that the ratio of wood and coal burning in contrast to fossil fuel combustion decreased until the 1980s, then the trend reversed (Gabrieli et al., 2010).

The source of BC measured in the Morteratsch forefield is charcoal or diagenetic coal. Charcoal particles were found by microscopic inspection, and the BPCA pattern corresponds to the BPCA pattern of charcoal and coal as described by Roth et al. (2012). The BPCA method, however, would also underestimate the amounts of soot-derived BC (Hammes et al., 2007). Potential sources for the BC in the Morteratsch proglacial area would be wood combustion for heating, charcoal kilns which were common in the area until the 20th century, or the railway (Rhaetische Bahn) which passes at a distance of about $2.5 \mathrm{~km}$ from the glacier front and that had been equipped with a steam engine until the 1920s.

In two rural areas of Switzerland and in the city of Zurich, burning of wood produced up to one-third of BC emissions (measured for $2.5 \mathrm{yr}$ on aerosols using a spectroscopic method) during the winter and 2-10\% during the summer (Herich et al., 2011). Szidat et al. (2007) even reported contributions of up to $88 \%$ of residential wood burning on particulate matter in Alpine valleys during winter. The analysis of 104 soil samples from the Swiss soil monitoring network showed that the $\mathrm{BC}$ concentrations had a very uniform distribution because of the uniform deposition of the atmospherically transported BC aerosols (Agarwal and Bucheli, 2011).

Up to now, BC concentrations have not been measured in initial soils of glacier forefields. A small decrease in the proportion of aromatic $\mathrm{C}$ with soil age has been found in the Damma glacier forefield using ${ }^{13} \mathrm{C}-\mathrm{NMR}$ (Dümig et al., 2011), while the proportion of aromatic $C$ in soil organic matter of the Morteratsch glacier forefield, measured using DRIFT, increased with time of exposure (Egli et al., 2010). This increase in aromatic compounds was, however, not related to fire-derived organic matter, but rather indicated the presence of condensed and lignin-derived compounds (Poirer et al., 2003).

Charred organic matter was deposited over the whole proglacial area. The amount of B6CA is slightly but not significantly higher in samples on older surfaces, which might indicate an effect of age or of different source material. Local fires could have influenced specific sites, especially S9 where the absolute $\mathrm{BC}$ concentration was considerable, or AS6 where the proportion of $\mathrm{BC}$ at $\mathrm{C}_{\mathrm{org}}$ and the proportion of B6CA were highest. The youngest soils were characterised by very low $\mathrm{C}_{\text {org }}$ concentrations, which resulted in a higher proportion of $\mathrm{BC}$ in these soils. This is reflected by the $\mathrm{H} / \mathrm{C}$ ratios which are rather low in the youngest soil samples. Here, specific initial microbial communities consequently may profit from this additional $\mathrm{C}$ source during the first years of soil evolution, as was shown for the Austrian Alps by Bardgett et al. (2007), and potentially promote soil development in its early stage.

\section{Conclusion}

The developing soils in the Morteratsch proglacial area contained charred organic matter, most likely derived from charcoal or coal, which was distributed over the entire investigated area. It is, however, not known if all BC was deposited by atmospheric deposition, or if the source of $\mathrm{BC}$ was material that accumulated on the glacier and was deposited on the parent material or soil after the ice finally melted. BC concentrations were lowest on surfaces that were exposed during the last $40 \mathrm{yr}$, either due to their lower exposure time or due to a reduced input of $\mathrm{BC}$ during the last $40 \mathrm{yr}$. $\mathrm{BC}$ contributed to total $\mathrm{C}_{\text {org }}$, which is particularly important at initial soil formation stages where microorganisms could use $\mathrm{BC}$ as a $\mathrm{C}$ source, whereas other $\mathrm{C}_{\text {org }}$ sources provided by vegetation were still scarce or simply lacking.

Acknowledgements. This research was supported by the Swiss National Foundation (SNF), project grant numbers 200021-117568 and 200021M_134479, and by the DFG grant EC 401/1-1. We thank I. Wieland, M. Wolf and G. Peschke for their assistance with laboratory analyses. We gratefully acknowledge Caroline Preston and an anonymous reviewer for their helpful comments that improved the manuscript.

Edited by: R. Conant

\section{References}

Agarwal, T. and Bucheli, T. D.: Is black carbon a better predictor of polycyclic aromatic hydrocarbon distribution in soils than total organic carbon?, Environ. Pollut., 159, 64-70, 2011.

Arimitsu, M. L., Piatt, J. F., and Romano, M. D.: Distribution of Ground-Nesting Marine Birds Along Shorelines in Glacier Bay, Southeastern Alaska: An Assessment Related to Potential Disturbance by Back-Country Users, Scientific Investigations Report 2007-5287, UW Dept of the Interior, US Geological Survey, Reston, Virginia, 2007.

Bardgett, R. D., Richter, A., Bol, R., Garnett, M. H., Bäumler, R., Xu X., Lopez-Capel, E., Manning, D. A. C., Hobbs, P. J., Hartley, I. R., and Wanek, W.: Heterotrophic microbial communities use ancient carbon following glacial retreat, Biol. Lett., 3, 487-490, 2007.

Bauer, H., Kasper-Giebl, A., Loflund, M., Giebl, H., Hitenberger, R., Zibuschka, F., and Puxbaum, H.: The contribution of bacteria and fungal spores to the organic carbon content of cloud water, precipitation and aerosols, Atmos. Res., 64, 109-119, 2002.

Bernasconi, S. M., Bauder, A., Bourdon, B., Brunner, I., Bünemann, E., Christl, I., Derungs, N., Edwards, P., Farinotti, D., Frey, B., Frossard, E., Furrer, G., Gierga, M., Göransson, H., Gülland, K., Hagedorn, F., Hajdas, I., Hindshaw, R., Ivy-Ochs, S., Jansa, J., Jonas, T., Kicka, M., Kretzschmar, R., Lemarchand, E., Luster, J., Magnusson, J., Mitchell, E. A. D., Olde Venterink, H., Plötze, M., Reynolds, B., Smittenberg, R. H., Stähli, M., Tamburini, F., Tipper, E. T., Wacker, L., Welc, M., Wiederhold, J. G., Zeyer, J., Zimmermann, S., and Zumsteg, A.: Chemical and biological gra- 
dients along the Damma glacier soil chronosequence, Switzerland, Vadose Zone J., 10, 867-883, 2011.

Bogdal, C., Bucheli, T. D., Agarwal, T., Anselmetti, F. S., Blum, F., Hungerbühler, K., Kohler, M., Schmid, P., Scheringer, M., and Sobek, A.: Contrasting temporal trends and relationships of total organic carbon, black carbon, and polycyclic aromatic hydrocarbons in rural low-altitude and remote high-altitude lakes, J. Environ. Monitor., 13, 1316-1326, 2011.

Brodowski, S., Rodionov, A., Haumaier, L., Glaser, B., and Amelung, W.: Revised black carbon assessment using benzene polycarboxylic acids, Org. Geochem., 36, 1299-1310, 2005.

Bucheli, T. D., Blum, F., Desaules, A., and Gustafsson, O.: Polycyclic aromatic hydrocarbons, black carbon, and molecular markers in soils of Switzerland, Chemosphere, 56, 1061-1076, 2004.

Büchi, H.: Der variskische Magmatismus in der östlichen Bernina (Graubünden, Schweiz), Schweiz. Miner. Petrog., 74, 359-371, 1994.

Burga, C. and Perret, R.: Vegetation und Klima der Schweiz seit dem jüngeren Eiszeitalter, Ott Verlag, Thun, 1998.

Burga, C. A., Krüsi, B., Egli, M., Wernli, M., Elsener, S., Ziefle, M., and Mavris, C.: Plant succession and soil development on the foreland of the Morteratsch glacier (Pontresina, Switzerland): straight forward or chaotic?, Flora, 205, 561-576, 2010.

Dümig, A., Smittenberg, R., and Kögel-Knabner, I.: Concurrent evolution of organic and mineral components during initial soil development after retreat of the Damma glacier, Switzerland, Geoderma, 163, 83-94, 2011.

Eckmeier, E., Egli, M., Hagedorn, F., and Schmidt, M. W. I.: Preservation of fire-derived carbon compounds and sorptive stabilization promote the accumulation of organic matter in black soils of the Southern Alps, Geoderma, 159, 147-155, 2010.

Egli, M., Wernli, M., Kneisel, C., and Haeberli, W.: Melting glaciers and soil development in the proglacial area Morteratsch (Swiss Alps): I. soil type chronosequence, Arct. Antarct. Alp. Res., 38, 499-509, 2006.

Egli, M., Mavris, C., Mirabella, A., Giaccai, D., Kägi, B., and Haeberli, W.: Soil organic matter formation along a chronosequence in the Morteratsch proglacial area (Upper Engadine, Switzerland), Catena, 82, 61-69, 2010.

Fitze, P. F.: Zur Relativdatierung von Moränen aus der Sicht der Bodenentwicklung in den kristallinen Zentralalpen, Catena, 9, 265-306, 1982.

Gabrieli, J., Vallelonga, P., Cozzi, G., Gabrielli, P., Gambaro, A., Sigl, M., Decet, F., Schwikowski, M., Gäggeler, H., Boutron, C., Cescon, P., and Barbante, C.: Post 17th-century changes of European PAH emissions recorded in high-altitude Alpine snow and ice, Environ. Sci. Technol., 44, 3260-3266, 2010.

Gamper, M.: Morphochronologische Untersuchungen an Solifluktionszungen, Moränen und Schwemmkegeln in den Schweizer Alpen, Schriftenreihe Physische Geographie, 17, Geographisches Institut, Universität Zürich, Zürich, 1985.

Gibbs, M. T. and Kump, L. R.: Global chemical erosion during the last glacial maximum and the present: sensitivity to changes in lithology and hydrology, Paleoceanography, 9, 529-543, 1994.

Glaser, B., Haumaier, L., Guggenberger, G., and Zech, W.: Black carbon in soils: the use of benzenecarboxylic acids as specific markers, Org. Geochem., 29, 811-819, 1998.
Hammes, K., Smernik, R. J., Skjemstad, J. O., Herzog, A., Vogt, U. F., and Schmidt, M. W. I.: Synthesis and characterisation of laboratory-charred gras straw (Oryza sativa) and chestnut wood (Castanea sativa) as reference materials for black carbon quantification, Org. Geochem., 37, 1629-1633, 2006.

Hammes, K., Schmidt, M. W. I., Smernik, R. J., Currie, L. A., Ball, W. P., Nguyen, T. H., Louchouarn, P., Houel, S., Gustafsson, O., Elmquist, M., Cornelissen, G., Skjemstad, J. O., Masiello, C. A., Song, J., Peng, P., Mitra, S., Dunn, J. C., Hatcher, P. G., Hockaday, W. C., Smith, D. M., Hartkopf-Froeder, C., Boehmer, A., Luer, B., Huebert, B. J., Amelung, W., Brodowski, S., Huang, L., Zhang,W., Gschwend, P. M., Flores-Cervantes, D. X., Largeau, C., Rouzaud, J. N., Rumpel, C., Guggenberger, G., Kaiser, K., Rodionov, A., Gonzalez-Vila, F. J., GonzalezPerez, J. A., La Rosa, J. M. de, Manning, D. A. C., LopezCapel, E., and Ding, L.: Comparison of quantification methods to measure fire-derived (black/elemental) carbon in soils and sediments using reference materials from soil, water, sediment and the atmosphere, Global Biogeochem. Cy., 21, GB3016, doi:10.1029/2006GB002914, 2007.

Herich, H., Hueglin, C., and Buchmann, B.: A 2.5 year's source apportionment study of black carbon from wood burning and fossil fuel combustion at urban and rural sites in Switzerland, Atmos. Meas. Tech., 4, 1409-1420, doi:10.5194/amt-4-1409-2011, 2011.

IUSS Working Group: World Reference Base for Soil Resources 2006, 2nd Edn., World Soil Resources Reports No. 103, FAO (Food and Agriculture Organisation of the United Nations), Rome, 2006.

Kim, S., Kramer, R.W., and Hatcher, P. G.: Graphical method for analysis of ultrahigh-resolution broadband mass spectra of natural organic matter, the Van Krevelen diagram, Anal. Chem., 75, 5336-5344, 2003.

Kim, Y., Hatsushika, H., Muskett, R. R., and Yamazaki, K.: Possible effect of boreal wildfire soot on Arctic sea ice and Alaska glaciers, Atmos. Environ., 39, 3513-3520, 2005.

Kim, J. H., Peterse, F., Willmott, V., Kristensen, D. K., Baas, M., Schouten, S., and Damste, J. S. S.: Large ancient organic matter contributions to Arctic marine sediments (Svalbard), Limnol. Oceanogr., 56, 1463-1474, 2011.

Lavanchy, V. M. H., Gäggeler, H. W., Schotterer, U., Schwikowski, M., and Baltensperger, U.: Historical record of carbonaceous particle concentrations from a European high-alpine glacier (Colle Gnifetti, Switzerland), J. Geophys. Res., 104, 21227-21236, 1999.

Magny, M.: Holocene lake-level fluctuations in Jura and the northern subalpine ranges, France, regional pattern and climatic implications, Boreas, 21, 319-334, 1992.

Maisch, M.: Die Gletscher Graubündens: Rekonstruktion und Auswertung der Gletscher und deren Veränderung seit dem Hochstand von 1850 im Gebiet der östlichen Schweizer Alpen (Bündnerland und angrenzende Regionen), Schriftenreihe Physische Geographie, 32, Universität Zürich-Irchel, Zürich, 1992.

Mavris, C., Egli, M., Plötze, M., Blum, J., Mirabella, A., Giaccai, D., and Haeberli, W.: Initial stages of weathering and soil formation in the Morteratsch proglacial area (Upper Engadine, Switzerland), Geoderma, 155, 359-371, 2010.

Mindl, B., Anesio, A. M., Meirer, K., Hodson, A. J., LaybournParry, J., Sommaruga, R., and Sattler, B.: Factors influencing 
bacterial dynamics along a transect from supraglacial runoff to proglacial lakes of a high Arctic glacier, FEMS Microbiol. Ecol., 59, 307-317, 2007.

Nocentini, C., Certini, G., Knicker, H., Francioso, O., and Rumpel, C.: Nature and reactivity of charcoal produced and added to soil during wildfire are particle-size dependent, Org. Geochem., 41, 682-689, 2010.

Oehl, F., Schneider, D., Sieverding, E. and Burga, C. A.: Succession of arbuscular mycorrhizal communities in the foreland of the retreating Morteratsch glacier in the Central Alps, Pedobiologia, 54, 321-331, 2011.

Patzelt, G.: Der zeitliche Ablauf und das Ausmass postglazialer Klimaschwankungen in den Alpen, in: Dendrochronologie und postglaziale Klimaschwankungen in Europa, edited by: Frenzel, B., Erdwissenschaftliche Forschung, 13, Franz Steiner Verlag, Wiesbaden, 248-259, 1977.

Poirer, N., Derenne, S., Balesdent, J., Mariotti, A., Massiot, D., and Largeau, C.: Isolation and analysis of the non-hydrolysable fraction of a forest soil and an arable soil (Lacadée, Southwest France), Eur. J. Soil Sci., 54, 243-255, 2003.

Renner, F.: Beiträge zur Gletschergeschichte des Gotthardgebietes und dendroklimatologische Analysen an fossilen Hölzern, Schriftenreihe Physische Geographie, 8, Geographisches Institut, Universität Zürich, Zürich, 1982.

Roth, P. J., Lehndorff, E., Brodowski, S., Bornemann, L., SanchezGarcía, L., Gustafsson, Ö., and Amelung, W.: Differentiation of charcoal, soot and diagenetic carbon in soil: method comparison and perspectives, Org. Geochem., 46, 66-75, 2012.

Spillmann, P.: Die Geologie des penninisch-ostalpinen Grenzbereichs im südlichen Berninagebirge, PhD thesis, ETH Zürich, Switzerland, 1993.
Stoffyn-Egli, P., Potter, T. M., Leonard, J. D., and Pocklington, R.: The identification of black carbon particles with the analytical scanning electron microscope: methods and initial results, Sci. Total Environ., 198, 211-223, 1997.

Stubbins, A., Hood, E., Raymond, P. A., Aiken, G. R., Sleighter, R. L., Hernes, P. J., Butman, D., Hatcher, P. G., Striegl, R. G., Schuster, P., Abdulla, H. A. N., Vermilyea, A. W., Scott, D. T., and Spencer, R. G. M.: Anthropogenic aerosols as a source of ancient dissolved organic matter in glaciers, Nat. Geosci., 5, 198201, 2012.

Szidat, S., Prévôt, A. S. H., Sandradewi, J., Alfarra, M. R., Synal, H.-A., Wacker, L., and Baltensperger, U.: Dominant impact of residential wood burning on particulate matter in Alpine valleys during winter, Geophys. Res. Lett., 34, L05820, doi:10.1029/2006GL028325, 2007.

Thevenon, F., Anselmetti, F. S., Bernasconi, S. M., and Schwikowski, M.: Mineral dust and elemental black carbon records from an Alpine ice core (Colle Gnifetti glacier) over the last millennium, J. Geophys. Res., 114, D17102, doi:10.1029/2008JD011490, 2009.

Trommsdorff, V. and Dietrich, V.: Grundzüge der Erdwissenschaften, 6th Edn., vdf-Verlag, Zurich, Switzerland, 1999.

Wientjes, I. G. M., Van de Wal, R. S. W., Reichart, G. J., Sluijs, A., and Oerlemans, J.: Dust from the dark region in the western ablation zone of the Greenland ice sheet, The Cryosphere, 5, 589-601, doi:10.5194/tc-5-589-2011, 2011.

Xu, B., Cao, J., Hansen, J., Yao, T., Joswia, D. R., Wang, N., Wu, G., Wang, M., Zhao, H., Yang, W., Liu, X., and He, J.: Black soot and the survival of Tibetan glaciers, P. Natl. Acad. Sci. USA, 106, 22114-22118, 2009. 